\title{
THE CONCEPT OF OFFENSE IN THE NEW CRIMINAL CODE
}

\author{
E. G. Simionescu
}

\author{
Elena-Giorgiana Simionescu \\ Faculty of Juridical Sciences, \\ "Constantin Brâncuşi” University of Târgu-Jiu, Romania \\ *Correspondence: Elena Giorgiana Simionescu, Faculty of Juridical Sciences, \\ "Constantin Brâncuşi”" University of Târgu-Jiu, Victoria Street, no. 24, Târgu - Jiu, Gorj, \\ Romania \\ Email: giorgiana_simionescu@yahoo.com
}

\begin{abstract}
As an important part of the general theory of crime, the concept of "crime" and generates continuously generated controversial discussions in the literature reflected differently in criminal law. The new Romanian Criminal Code, although deemed necessary legal definition of the offense by listing its essential features, devotes a formally defined, giving the idea that crime is the fact that social threat.
\end{abstract}

Keywords: offense, provision crime by criminal law, criminal culpability, unjustified, imputable character

\section{Introduction}

The term comes from the Latin word crime "infractio,-onis" = to break, to break through French Connection "infraction" = offense ${ }^{1}$. In common parlance, the word has the meaning of "deviation", "breach of an order" and that the "violation of a law that deserves to be punished by criminal punishment," "socially dangerous offense consisting in breach of a criminal law, the commission, is guilty of a deviation from the criminal law and is punishable by law", (in English, "infraction", "offense"3). This latter understanding of crime is common in criminal law designating as "socially dangerous act that, if committed with guilt, under the criminal law", the new "offense under the criminal law committed with guilt, unjustified and imputable to the person who committed"5 a crime and legal institution that, along with two other fundamental institutions of criminal and criminal penalties, the skeleton, the "pillars" of criminal law ${ }^{6}$. Within and around them revolve all applicable criminal law.

\section{Definition of the offense}

New legislator Romanian Criminal Code (2009) defines in a new offense, giving the idea that crime is the fact that social threat, so that the provisions of art. 15 para. 1, Romanian Penal Code (RPC) provides that the offense "under the criminal law act committed with guilt, unjustified and imputable to the person who committed it."

\footnotetext{
${ }^{1}$ V. Paşca, Drept penal. Partea generală, Worldteach Publishing House, Timişoara, 2005, p. 219.

${ }^{2}$ Details: http://dexonline.ro/definitie/infractiune.

${ }^{3}$ Mirabela Rely Odette Curelar, Dicționar juridic Român-Englez, "Academica Brâncuşi” Publishing House, Târgu-Jiu, 2011, p. 93.

${ }^{4}$ Art. 17 para. 1 Penal Code (Law no. 15 of 21.06.1968 - Romanian Penal Code, republished in Official Gazette of Romania, Part. I, No. 65 of 16.04.1997, with subsequent amendments).

${ }^{5}$ Art. 15 para. 1 Penal Code - Law no. 286 of 17.07.2009 Romanian Penal Code, published in Official Gazette of Romania, Part. I, no. 510 of 24.07.2009, with subsequent amendments (in force since 01.02.2014).

${ }^{6}$ Ioan Oancea, in V. Dongoroz and collaborators, Explicații teoretice ale Codului penal român, volume I, Partea generală, "Editura Academiei" Press, Bucharest, 1969, p. 99.
} 
Specialized Romanian literature, he expressed the view that the concept of social danger not only to complete the provision provided the offense in the criminal law, because only the legislature criminalizes threatening social facts which affect the values protected by criminal law. ${ }^{7}$ Indeed, the legislature is held to choose between the amounts recognized at some point, those who, because of their importance can not be effectively protected by means of other branches of law, associating them criminal protection. Also, the actions likely to affect these values should not attract criminal than the rules of those events that harm the highest degree protected value ${ }^{8}$. Therefore, we can say with reason that the requirement that the offense under the criminal law to express the idea that she share the default risk ${ }^{9}$.

The legal definition of the crime is a legal instrument of absolute necessity for the theory of criminal law, but also for legal practice as competent authorities to enforce the law, reporting their data to the hard facts from the legal concept of crime solving will determine whether they realize it or not features essentials of the offense, whether or not they fell within criminal illicit. This definition should be seen not only as an outline of the fundamental category of criminal law ${ }^{10}$, but as a rule of law which limits the scope of illicit criminal circumscribing it, under this legal basis, the scope of criminal offenses covered by other facts regulation of other categories of legal rules ${ }^{11}$ (administrative, disciplinary, etc.) ${ }^{12}$.

If features will coincide with the facts described in the rule of criminality, it means that he violated the will of the legislature, and the deed will be an offense and shall be liable to the penalty provided by law.

Adoption of such legislation to the general concept of crime is important for the following reasons:

- Using this you can easily know the general concepts and facts characterize the field as crimes and at the same time, it can easily delineate and separate field field offenses considered misdemeanors or willful acts causing injury to civilians;

- All other provisions relating to offenses, in part, are subject to the provisions of the general notion of crime because all crimes must meet specific criteria and features of the general notion of crime;

- The definition of the offense is a legal regulation in the sense that it is normative and contains a rule of law that is binding on the judge and the citizen.

Examination of the concept of crime within the meaning of the definition of art. 15 para. 1 RPC, by stating its essential traits, that any of the offenses under the penal law to be treated as such, must meet the following essential features: the act or under the criminal law, the offense is committed with guilt, the act be unwarranted act is attributable to the person who committed it.

\section{Analysis of the essential features}

1. Providing criminal offense by law is the first condition of existence of any crime. It follows from the principle of legality of criminal offenses (art. 1 para. 1 RPC) so that in the absence of this condition, the act does not constitute infringement.

It should be emphasized, however, that the concepts of crime and, respectively, offense under the criminal law are not synonymous. If any offense must be an offense under the criminal law, not every act is an offense under the criminal law. For this offense under the criminal law must meet the other conditions: namely, to be committed with guilt is unjustified, be attributed to the person who committed it.

\footnotetext{
${ }^{7}$ G. Antoniu, Tipicitate şi antijuridicitate, "Revista de Drept Penal” Review, no. 4/1997, p. 23.

${ }^{8}$ In international criminal law are international criminalize those acts affecting particularly important values of the international community assembly (Laura Magdalena Trocan, Curtea Penală Internațională, published in conference volume, conference with international participation "Gorjeanul în mileniul trei", organized by "Constantin Brancuşi”" University of Târgu-Jiu, "Gorjeanul” Publishing House, Târgu-Jiu, 2005).

${ }^{9}$ F. Streteanu, Drept penal. Partea generală " "Rosetti” Publishing House, Bucharest, 2003, p. 290.

${ }^{10}$ Ioan Oancea, Explicații teoretice, vol. I, op. cit., p. 104.

${ }^{11}$ For the definition of international crime, see Laura Magdalena Trocan, op. cit., 2005.

${ }^{12}$ Maria Zolyneak, Drept penal, volume II, "Fundația Chemarea" Publishing House, Iaşi, 1993, p. 142.
} 
Offense of criminal law provision expresses the existence of three realities ${ }^{13}$ :

a) the existence of facts (action or inaction) by the respective result;

b) the existence of a legal model of criminality;

c) specific offense characteristics coincide with the legal model of criminality.

a) Under the first aspect, it is understood that the offense can not be considered only as an outward manifestation of man, whether it acts directly on the world around us, whether set in motion a foreign power, which connects to achieve certain effects, or use of inanimate objects as an extension of his own making in this way states objectives ${ }^{14}$. Mere mental processes (simple thoughts) that occur in the person's mind may not be criminal ${ }^{15}$, as the reaction of animals, natural phenomena.

The outward manifestation to human bias, should express his free will, the subject having an accurate representation of the action (inaction) and its consequences. Action involves energy consumption and can take the form of acts or gestures (hitting, destruction, threat) may consist of written words or acts (forgery of documents, false allegations). Failure involves staying in passive agent relative to its obligation to act.

b) Under the second aspect, the crime involves the pre-existence of a rule of criminality that is described in the deed that the legislature intends to prohibit or order it ${ }^{16}$. Incrimination rule includes not only elements of the offense describing objectives and subjective. Otherwise, the offense charged, without subjective element has no legal relevance. For example, killing a person has legal significance only if the act was committed with guilt ${ }^{17}$ otherwise suppressing a person's life would not differ from that caused by natural events (epidemics, floods, earthquakes, landslides, flood, lightning, tornadoes, heat, frost, etc.).

Offense of criminal law provision applies not only to the fait accompli, but attempt, as the offense committed venture (the act as co-author, instigator, accomplice). Incrimination rule established in the special part of the Criminal Code make not only with the general rule, but it can be completed with a rule in another branch of law: family law ${ }^{18}$, administrative law ${ }^{19}$, labor law.

Also providing offense of criminal law must be verified as having an objective existence, legal model should be effective in practice, not in the mind of the perpetrator (putative character).

c) Under the third part, the offense involves a full line of concrete features of the scene with the rule of criminality ${ }^{20}$. This line $\left(\right.$ typical $^{21}$ ) may appear in a form typical perfect (the consummated crime), atypical imperfect (tentative contribution instigator, accomplice) or past perfect (actually crimes exhausted).

\footnotetext{
${ }^{13}$ G. Antoniu (coordinator), C. Bulai, C. Duvac, I. Griga, Gh. Ivan, C. Mitrache, I. Molnar, V. Paşca, O. Predescu, Explicații preliminare ale noului Cod penal, volume I, "Universul Juridic" Publishing House, Bucharest, 2010, p. 140.

${ }^{14}$ George Antoniu (coordinator), op. cit., p. 140.

${ }^{15}$ No one can be punished for merely thinking, according to the Latin maxim "Cogitationis poenam nemo patitur" (Ulpian).

${ }^{16}$ G. Antoniu (coordinating) and associates, op. cit., 2010, p. 141.

${ }^{17}$ Art. 16 para. 1 Romanian Penal Code: "The act is an offense only if committed with guilt as required by the criminal law". Art. 16 para. 2 Romanian Penal Code: "Guilt is when the offense is committed with intent, negligence or intentionally exceeded".

${ }^{18}$ For example, criminalize family abandon (art. 378 Romanian Penal Code) refers to the rules of family law. For details, see P. Dungan, Comentariu privind unele infracțiuni din Codul penal, Worldteach Publishing House, Timişoara, 2007, pp. 102-105; A. Gh. Gavrilescu, Drepturile şi obligațiile părinteşti, "Universul Juridic" Publishing House, Bucharest, 2011, p. 282.

${ }^{19}$ The incrimination rule on abuse of office (Art. 297 Romanian Penal Code), and the incrimination rule misconduct in service (art. 298 Romanian Penal Code), referring to the powers of public officials, make the provisions of administrative law. For details, see P. Dungan, T. Medeanu, V. Paşca, Manual de drept penal. Partea specială, "Universul Juridic" Publishing House, Bucharest, 2011, pp. 219-226; I. C. Rujan, Drept penal. Partea specială I, "Didactică şi Pedagogică” Publishing House, Bucharest, 2007, pp. 121-129.

${ }^{20}$ G. Antoniu (coordinating) and associates, op. cit., 2010, p. 143.

${ }^{21}$ G. Antoniu, Tipicitate şi antijuridicitate, "Revista de Drept Penal” Review, no. 4/1997, p. 23.
} 
In modern criminal doctrine term "typical" is used to express the idea that facts which meets all standard features of criminality abstract model (type) describes an act determined that the offense, as an offense ${ }^{22}$.

Typicality is achieved only as a result of comparing the content objective facts that the rule of criminality, as in content topics operates with the notion of guilt as an essential feature of the offense. Typicality not be confused with criminality rule because typicality is an assimilation of facts (it is typical that its features correspond to the facts described), while the legal model only serves as a comparison with reality.

This line should be objective, not imagining perpetrator (putative act has no criminal relevance).

In this respect, the legislature develop legal model based on observation of realitylegislative acts that evaluates and substantially reduce certain traits with which formulates incrimination rule. This reality suggests, requires the development of rule and give, while concrete material which arises interdiction or included in the standard order of criminality. The facts is criminal only insofar as it is reflected in the content of a rule of criminality, ie only to the extent determined by the legislature corresponding features in the model in criminal norm. For example, criminalizing theft (art. 228 RPC) Romanian legislator lays down that a deed must meet to qualify as such: to consist in making an action to have a movable object, that good to be in possession or detention of a person.

In criminal law enforcement activity, the judiciary will have to compare a specific act committed by a person described in the standard model act of criminality, to see if it meets all the requirements imposed by the legislature. The facts of the defendant $\mathrm{X}$ to $\mathrm{Y}$ enters his house and steal some money there corresponds entirely the offense described in art. 228 RPC Instead, the act of $\mathrm{Z}$, taking, the purpose of acquiring a good find on the street, does not meet the legal model, as the goods are not in possession of someone else at the time, being a good lost.

Although incrimination rule contains the description of both the objective elements of the offense charged and of the subjective norm conformity with facts criminality is understood by only a typical expression according to objective, factual features concrete objective requirements of the standard wording of indictments. Regarding subjective features facts and compliance with the requirements of subjective criminality rule they are analyzed in the framework of the two essential features of the offense, namely guilt, which is a distinctive feature of the offense.

2. Guilt is the second essential feature of the offense. The doctrine of limited criminal culpability to those psychological processes that arouse the idea of the subject criminal, drives the action, directs and controls the physical activity itself ${ }^{23}$.

This implies that the act is an expression of the subject's mental attitudes regarding willingness to commit the act and its consequences character and conscience.

Crime as any act of human conduct, is not only a natural material side, and an internal side, mental, made up of all psychic phenomena and processes that precede and accompany the administration of Conduct. As a mental attitude of the perpetrator of the crime committed and its consequences ${ }^{24}$ to guilt is the result of interaction of two factors: consciousness or intellect factor will or volitional factor.

Criminal law defines not guilty, but the provisions of art. 16 RPC, Consecrating forms of guilt, states that "(1) The act is an offense only if committed with guilt as required by the criminal law. (2) Guilt is when the offense is committed with intent, recklessly or intentionally exceeded. (3) The offense is committed when the perpetrator intentionally: a)

\footnotetext{
${ }^{22}$ Idem, p. 15.

${ }^{23}$ I. Mircea, Vinovăția în dreptul penal român, Lumina Lex Publishing House, Bucharest, 1998, p. 27.

${ }^{24}$ Elena Giorgiana Simionescu, Distincție între vinovăție ca trăsătură esențială a infracțiunii şi vinovăție ca element al conținutului constitutiv al unei infracțiuni, "Drept şi societate”Review, no. 2/2003, "Academica Brâncuşi” Publishing House, Târgu-Jiu, 2003, pp. 178-188.
} 
states the result of his act, following its production by committing that act, b) states the result of his act and, although it seeks to accept the possibility. (4) The offense is committed by negligence, the perpetrator: a) states the result of his act, but do not accept it, believing without reason that he will not produce, b) does not require the result of his act, although it should be able to provide. (5) There intentionally exceeded the act consisting of a deliberate action or inaction produces a more serious fault is due to the perpetrator. (6) The act consisting of an act or omission constitutes an offense when committed intentionally. Negligent act committed an offense only when expressly provided by law. "

It may be noted that the scope of acts committed with guilt are introduced not only the intentional or negligent, but also intentional exceeded.

The literature has defined guilt as "the mental attitude of the perpetrator which consists in an act of conscience and will to the offense committed and its consequences, an attitude that manifests as intent or negligence" 25 or "attitude of conscious will offender to act and follow synthesized with the intention or fault that commits an act dangerous to society",26.

Since no account was taken of the relationship between guilt and other key features of the offense (as were regulated by Romanian Criminal Code of 1968, republished in 1997, with subsequent amendments) and the specificity of the two factors in the above definition required to complete the definition of guilt in criminal doctrine, designating, the mental attitude of the person who committed an act which will unconstrained social threat, under the criminal law, had, in carrying out the representation of socially dangerous act and its consequences or, although not had representation act and its consequences, had the real possibility of that representation" 27 .

The concept of criminal law current Romanian (Romanian Criminal Code of 2009, as amended and supplemented), guilt is seen as a process of consciousness composed of two factors: the intellectual process and a volitional process. Thus, guilt is not a mere possibility of representation or representation act and therefore it reflects the attitude subject to social values protected by law.

For there to be guilty, the person who committed the crime should be responsible for his actions meaning and values that can master them and direct responsibility of assuming the existence of two factors, the intellectual and volitional.

Lack of either nonexistent crime, the lack of guilt. For the existence of the offense, the act of consciousness and free will shall be expressed, uncorrupted and unaltered, if, however, the conscience and the offender will have been vitiated by error constraint is not guilty and therefore crime.

As an essential feature of the crime, guilt takes three main forms: intent, negligence and intent expired. In turn, the first forms are liable individually different ways: direct and indirect intent, fault with the provision and simple fault.

The intention is that form of knowledge provided in article. 16 para $3 \mathrm{RPC}$, which is when the person who commits an offense, provided the time of the offense, the result of its socially dangerous and follows its production, or, although it seeks, accepts, however, the event's occurrence.

Direct intention is characterized in that the perpetrator provides the result and its aims by committing to production. It is the most serious form of criminal conduct awareness by the perpetrator assumes the moral act. Example: person shoot a gun into the victim of a few centimeters $^{28}$, the person hitting the victim several times in the head with a blunt object, causing his death, the person who applied the victim more hits in a vital area etc..

\footnotetext{
${ }^{25}$ Maria Zolyneak, op. cit., p. 20.

${ }^{26}$ Ioan Oancea, op. cit., p. 183.

27 C. Bulai, B. N. Bulai, Manual de drept penal. Partea generală, "Universul Juridic" Publishing House, Bucharest, 2007, p. 118.

${ }^{28}$ C.S.J., Criminal decision, no. 505/1999.
} 
There is the way of the intention when the perpetrator is action or inaction, the way of making the result of the leading socially dangerous act in these circumstances he desired to produce that result. The finding that the perpetrator of the offense and that he deliberately set out its dangerous outcome is evidence that he intended producing that result. Direct intention of two components as follows: provision outcome and follow-up of its production.

Provision outcome is not possible without a previous representation shift action, the whole anti-social behavior and its consequences provision. It also requires a conscious involvement in the criminal opt for deliberation and under a previous motivations for decision making and conscious shift from a criminal offense, the offender represents the entire conduct of the action or inaction and its consequences it, both from the physical, material, and as social relation, criminal. Representation and make provision therefore essential meaning of the phenomenon of intentional moral understanding and ownership of the offense.

Tracking result highlights separately subjective attitude of active engagement and persistent offender to the consequences of his act, the harmful consequences resulting there from. The perpetrator acts with intent not only when the result is producing the very purpose of his action or inaction, but also when its production is seen by him as a necessary or inevitable as a caregiver intended result. Therefore, when the result set as inevitable, and the perpetrator acts to produce it, there are direct intent, even if the consequences were not all he desired. There are crimes that, in terms of guilt, can only appear in the form of direct intent. For example, the crime of embezzlement is committed with direct intent only because the law (art. 295 RPC) shows that ownership, use or trafficking are in the interest of officer or manager or to another. The same situation encountered in theft, robbery etc.

Indirect intention (possibly willful) is characterized in that the perpetrator, though provide the result of not following him, but accepts the possibility of production. Example: hitting the victim in the stomach with his fist and feet, with deadly consequences for this ${ }^{29}$; instigating dogs on the victim, causing serious injuries due to biting and tearing the limbs etc.

As a form of guilt, indirect intention to commit the crime occurs that can produce at least two results. To a result of the offender 's mental position tracking of the realization that (direct intention), this result can be both licit or illicit. Compared to the second result, the position of the offender 's psychological acceptance of the possibility of (indirect intention).

Because the second result may occur, is called indirect intention possible. Compared to this result possibly offender has an indifferent attitude, acceptance of his generation, but if the result prescribed by the offender appears inevitable intention that commits such an act is direct, although not all results are tracked deed. Provide all the facts, which are part of the offenses in question, refers to the development of the causal connection between the offense committed and the result dangerous product. For the provision of intent is sufficient causal link to exist only in general features of principle.

Direct and indirect intention Between intention there are some differences. Thus, there is an intention to direct that the offender needed to be pursued occurrence consequences of his act, which has provided. The result is either the sole aim pursued by the defendant, is an indispensable means to achieve another goal. Unlike direct intent, indirect intent that the offender need not follow the result of its occurrence, but to accept, consciously, the possibility of occurrence. Lack of desire in terms of consequences of acts committed occurrence can occur either through indifference to those consequences, or even the lack of desire as they appear, they actually occurring due to action or inaction perpetrator ${ }^{30}$.

Specialized legal literature ${ }^{31}$, in addition to the normative ways of intent (direct and indirect) are distinguished: general intent (simple) special intention (qualified) positive intention and intention negative original intention and ultimate intention, intention determined undetermined intent intention and the intention of threatening damage; intention spontaneous

\footnotetext{
${ }^{29}$ C.S.J., Criminal decision, no. 101/2002.

${ }^{30}$ A. Boroi, Drept penal Partea generală, “C.H. Beck” Publishing House, Bucharest, 2009, pp. 91-93.

${ }^{31}$ V. Dongoroz, op. cit., pp. 194-196; G. Antoniu (coord.) and associates, op. cit., 2010, pp. 153-154.
} 
and premeditated intent (deliberate) single intention and complex intention, intention, etc. incidental primary intention. These arrangements contribute to judicial individualization of punishment, highlighting the outstanding degree of fault affecting the dangerousness of the offender.

The fault is that form of guilt under the provisions of art. 16 para. 4, RPC, which exists when the person committing an offense, provided the result of socially dangerous, but has not sought and did not accept the event of his, thinking, without reason, that it will not happen, or did not foresee the outcome, although should be able to provide.

Fault with the provision (easily, fears) ${ }^{32}$ is the offender provision of the dangerous consequences of his action or inaction, we do not accept, believing without reason but that they will not occur.

Fault with the provision is characterized by two factors: the existence of the person of the consequences of his criminal provision and existence expectancy, groundless, not to produce or to prevent their own actions or the support of other people.

Negligent acts committed with provision meet very often in judicial practice in road traffic. For example, the act does not reduce speed driver that you pass groups of people, with the possibility of an accident, a result that does not accept and believe, wrongly, that it can not occur, but the result still occurs. In this situation, the driver has committed the offense of breach of provision.

The offender provision of the dangerous consequences of his act makes ease to resemble direct or indirect intent. If fault with provision (ease), but there is a desire to produce the track and no acceptance of the possibility of their occurrence, elements characterizing intention. For ease, providing follow-up actions or inactions offender may be only a provision of the possibility of their occurrence, as only in this case can be no hope, no reason, however, to prevent such consequences. If provision inevitability consequences occurred, there can be no hope that they will produce, we hope to prevent or avoid the situation in which it was assessed that the person acts with direct intent. What distinguishes fault with indirect intent is no provision in the first admission of dangerous consequences occurred conscious set. When the offender deliberately hopes it can prevent the consequences of his act, watch you provided, there can be no conscious admission occurrence of these consequences. Hoping to prevent the consequences provided by the perpetrator employs certain circumstances; unfounded opinion of the person must remove the possibility of their occurrence in reality.

Since the distinction between intention and negligence indirectly with the only provision in terms of subjective mental position, acceptance or rejection of the result, it requires analysis of objective issues may result in the form of guilt ${ }^{33}$. The criminal doctrine showed that if indirect intent, the offender has an indifferent attitude of acceptance towards the outcome that it provides, as it does nothing to prevent the outcome, remain passive and with provision for fault result set is not supported accepting attitude resulting from the perpetrator who hope to prevent, based on objective factors related to the circumstances in which the activity takes place, the properties of the instrument with which it acts and subjective factors.

Nevertheless prove insufficient misjudged as dangerous outcome occurs. Offense is committed negligently with foresight, as the perpetrator of misjudged, superficial, prevention possibilities of negative outcome.

Simple fault (without provision, error, and negligence) is the position of the person who has provided psychological dangerous consequences of his act, although in all circumstances of the case and on the basis of its ability to be able to provide for them.

In case of an offense of criminal negligence is consciously disregards rules of conduct, precautions to be taken in different situations without providing dangerous consequences of his actions. Therefore, in the event of negligence, there is no question the person's attitude

\footnotetext{
${ }^{32}$ C. Bulai, op. cit., p. 120.

${ }^{33}$ A. Boroi, op. cit., p. 95.
} 
towards the consequences of his actions, the willingness to produce or accepting aware of the possibility of their occurrence, consequences that have not provided, although it was able to provide for them. For example, a pharmacist shall, inadvertently, a different medicine than shown or incorrectly prepared a harmful drug, a technician works on a construction site and not from neglect, labor protection measures was required, in which case they grieve someone's injury or death.

One who has committed a crime of negligence in this context, rejects binding rules of conduct in that case, so is not necessary to think about these rules and the consequences they can produce deeds. This disregard of the rules of conduct and the consequences of not providing needed and could be provided, as a basis for establishing criminal liability in case of negligence. Negligence, as a form of guilt, can be characterized based on two elements: a negative element, which refers to the lack of provision of dangerous consequences of acts committed by the subject of the offense and a positive, indicating the existence of conditions which enable to believe that the offender should be able to foresee harmful consequences of his action or inaction.

The report negative element, negligence differs from direct and indirect intent and guilt of provision. The report positive element, negligence differs from fortuitous because the subject must be able to foresee the consequences of his actions, which is not required in case of fortuitous case eliminating the criminal nature of the act.

To establish guilt in the form of simple fault using two criteria: an objective criterion by which user seeks to determine whether the offender should provide socially dangerous outcome and subjective criteria, which aims to determine whether the offender, who had to provide the result of his act, had in fact can provide this result, if it can provide the time of the offense $^{34}$. Objective criterion is to verify the circumstances of the offense are committed, to see if any normal human being careful perpetrator category, provide the result of his action or inaction. If it is determined that the result was predictable, so the offender does not have to provide is not considered to be committed with guilt (simple negligence) but fortuitous. If, however, it is established that the outcome was predictable, then the offender must provide, check if the situation could have foreseen. Concrete possibility of provision of the perpetrator is judged on his personality, life experience, training, intellectual development and other elements necessary for the correct situation. If after observing this subjective criterion establishes that the perpetrator could foresee the result, then guilt is as simple negligence. If the result of observation, subjective criterion is negative, meaning that the perpetrator could not predict the outcome, guilt guilt form can not be accepted, due to inability of the offender to provide subjective.

In the theory of criminal law are known and other ways of negligence ${ }^{35}$ : carelessness (recklessness), ignorance (imperitive), negligence, nonchalance, indifference (indifference) and so on, whose knowledge contributes to more accurate characterization of guilt and the sentence. It also is distinct from guilt in fault in agendo and omittendo, fault and fault specific generic $^{36}$.

Intention exceeded is set out in article. 16 para. 5, RPC, a mixed form of guilt arising from the union's intention to fault, characterized in that the subject of the offense requires and wants or accepts producing dangerous consequences, but the products are actually more serious, and that they provided, but reckoned without reason that it will not or has not provided, but could and should have foreseen.

What characterizes Intention exceeded is the fact that, following the occurrence of a particular outcome, the offender commits an act which constitutes the material element of an offense, but produces a more severe or further characterizing a more serious offense or an aggravated form of the same offense.

\footnotetext{
${ }^{34}$ A. Boroi, op. cit., p. 95.

${ }^{35}$ V. Dongoroz, op. cit., p. 201-202.

${ }^{36}$ A. Boroi, op. cit., p. 96.
} 
Romanian Criminal Code provides for such situations, criminalizing the offense of its own, for example, crash causing death or injury (art. 195, RPC) ${ }^{37}$ follow facts or aggravated versions of offenses in the contents of which were complex set such situations such as rape that resulted in the death of the victim (art. 218 par., 4 RPC $)^{38}$, robbery or piracy that resulted in the death of the victim (art. 236 par. 1, RPC), etc.

In all these cases, the initial action is an intentional and the result of extensive or further beyond the perpetrator's intention, leading to a more serious offense is committed negligently. If exceeded intent, the perpetrator acts with direct intent to produce a particular result, and the result of serious misconduct occurs.

The existence of this form of guilt, fault in producing different intention worst result exceeded the indirect intention because if the offender provided as a possible result of serious yet acted more serious offense can be committed only done intentionally indirect.

In conclusion, in terms of the offender's attitude towards the result of his act, we retain the following: if the result of direct intent is clear, if indirect intent result is possibly the fault to predict the outcome is unlikely or impossible, the result is unexpectedly simple negligence, and the result is seriously outdated intention or one more.

As an essential feature of the crime, guilt can exist in any of its modalities, the subjective aspect of the content of a specified offense; it can not exist only in the manner specifically provided by law. Guilt as a constitutive element content, there will be only when the material element of the offense was committed with guilt as required by law ${ }^{39}$. According to art. 16 paragraph 6 RPC "The act consisting of an act or omission constitutes an offense when committed intentionally. Negligent act committed an offense only when expressly provided by law. "In other words, all the incriminating facts described rule, actions or inactions, are committed only intentionally. Criminal liability for such offenses could be drawn and if the author has acted negligently, unless it is expressly provided by law.

3. Another essential feature is the unfair nature of the crime scene, an innovation of the Romanian legislature ${ }^{40}$, on the understanding that none of the grounds ${ }^{41}$ supporting constitute an essential feature of crime expressed, however, by negation. The solution leaves room for interpretation, because the value of "unjustified" is not equivalent to the value of the expression "lack supporting causes." The concept of "unjustified" has several meanings than the institution "lack of evidence causes" clearly defined reality that can eliminate the existence of a crime. In her opinion ${ }^{42}$, it was argued that these ways: self-defense, necessity ${ }^{43}$, exercise of any right or performance of an obligation, the injured person's consent may be expressed by the concept of "illicit".

The term "illicit" is used to express facts inconsistency with the requirements of the legal system as a whole. Typical "illicit" assessment of facts expressed by a negative condition, namely, that there should not be a cause supporting. Usually "illicit" facts is typical, that is at odds with the law in her ensemble. Only exception is not typical of "illicit" when higher requirements of the legal system removes its illegal nature, giving it a legitimate

\footnotetext{
${ }^{37}$ T. Toader, Drept penal român. Partea specială, "Hamangiu” Publishing House, Bucharest, 2009, p. 74.

${ }^{38}$ Idem, pp. 124-125.

${ }^{39}$ Gh. Nistoreanu, A. Boroi, Drept penal.Curs selectiv pentru licență, “All Beck” Publishing House, Bucharest, 2002 , p. 34.

${ }^{40}$ Law no. 286 of 17.07.2009 Romanian Penal Code, published in Official Gazette of Romania, Part. I, no. 510 of 24.07.2009, with subsequent amendments (in force since 01.02.2014).

${ }^{41}$ Art. 18 para 1 Romanian Penal Code "An act under the criminal law, if any of the causes provided by law supporting self-defense, necessity, exercise of any right or performance of an obligation, consent of the victim". ${ }^{4}$ G. Antoniu (coord.) and associates, op. cit., 2010, p. 146.

${ }^{43}$ And public international law self-defense can occur as a cause for the removal of the unlawful nature of the fact of violation of international obligations (see, to that effect Laura Magdalena Trocan, Sanctions in Public International Law, Dny práva - 2009 - Days of Law: the Conference Proceedings, 1. Edition, Faculty of Law, Masaryk University,

Brno, 2009http://www.law.muni.cz/sborniky/dny_prava_2009/files/prispevky/mezin_soud/Trocan_Laura_Magdalena. pdf).
} 
purpose (permitted), operating as supporting a cause that expresses precisely these requirements.

4. The second innovation that the definition of the offense is attributable to the character of the offense, and he attributes that leaves room for interpretation. The Romanian criminal doctrine notion of "imputation" expresses the idea that an act has been attributed to objective and subjective author it belongs ${ }^{44}$.

A person accused of a crime is to find that factor has influenced the will and conscience through it on the fact, that the guilt of his action. Therefore witnessing a repeat offense features because guilt has already been listed among them, the more so as, a connection between the material element and the immediate consequence, cause and effect, required by law for the offense there is causation that impose or to prove existing cases, and an element of the actus reus of the offense constituent content.

\section{Conclusions}

Romanian Penal Code 2009 defines new offense as "offense under the criminal law committed with guilt, unjustified and imputable to the person who committed it" features listed in order of priority has actually providing criminal law, and guilt, following two other key features, unjustified and imputable to the scene ${ }^{45}$.

\section{Bibliography}

I. Pascu, T. Dima, C. Păun, Mirela Gorunescu, V. Dobrinoiu, M. A. Hotca, I. Chiş, M. Dobrinoiu, Noul Cod Penal comentat, Partea generală, vol. I, "Universul Juridic" Publishing House, Bucharest, 2012;

Elena Giorgiana Simionescu, The intention, form of guilt in the romanian and foreign penal legislation, in Annals of "Constantin Brancusi" University of Târgu-Jiu, Legal Sciences Series, no. 3/2012;

Mirabela Rely Odette Curelar, Dicționar juridic Român-Englez, "Academica Brâncuşi”" Publishing House, Târgu-Jiu, 2011;

P. Dungan, T. Medeanu, V. Paşca, Manual de drept penal. Partea specială, "Universul Juridic" Publishing House, Bucharest, 2011;

A. Gh. Gavrilescu, Drepturile şi obligațiile părinteşti, "Universul Juridic" Publishing House, Bucharest, 2011;

G. Antoniu (coord.), C. Bulai, C. Duvac, I. Griga, Gh. Ivan, C. Mitrache, I. Molnar, V. Paşca, O. Predescu, Explicații preliminare ale noului Cod penal, vol. I, "Universul Juridic" Publishing House, Bucharest, 2010;

A. Boroi, Drept penal Partea generală, “C.H.Beck” Publishing House, 2009;

T. Toader, Drept penal român. Partea specială, "Hamangiu” Publishing House, Bucharest, 2009;

C. Bulai, B. N. Bulai, Manual de drept penal. Partea generală, "Universul Juridic" Publishig House, Bucharest, 2007;

P. Dungan, Comentariu privind unele infracțiuni din Codul penal, Worldteach Publishing House, Timişoara, 2007;

I. C. Rujan, Drept penal. Partea specială I, "Didactică şi Pedagogică" Publishing House, Bucharest, 2007; 2005;

V. Paşca, Drept penal. Partea generală, "Worldteach" Publishing House, Timişoara,

\footnotetext{
${ }^{44}$ V. Dongoroz, Explicații teoretice, volume I, Romanian Academy Publishing House, Bucharest, 1970, p. 104.

${ }^{45} \mathrm{In}$ appreciation of facts as the crime it is considered a person presumed innocent until there is a final judgment. (See, in this regard, L. M. Trocan, Garantarea dreptului la apărare în lumina dispozițiilor tratatelor internaționale specializate in materia drepturilor omului şi jurisprudenței CEDO, in Annals of "Constantin Brancusi" University of Târgu-Jiu, Legal Sciences Series, no. 4/2010, p.115).
} 
G. Antoniu, Cauze justificative în proiectul noului Cod penal, "Revista de Drept Penal" Review, no. 2/2004;

Elena Giorgiana Simionescu, Distincție între vinovăție ca trăsătură esențială a infracțiunii şi vinovăție ca element al conținutului constitutiv al unei infracțiuni, "Drept şi societate” Review, no. 2/2003, "Academica Brâncuşi” Publishing House, Târgu-Jiu, 2003;

F. Streteanu, Drept penal. Partea generală, "Rosetti" Publishing House, Bucharest, 2003;

Gh. Nistoreanu, A. Boroi, Drept penal.Curs selectiv pentru licență, "All Beck" Publishing House, Bucharest, 2002;

I. Mircea, Vinovăția în dreptul penal român, "Lumina Lex" Publishing House, Bucharest, 1998; 1993;

Maria Zolyneak, Drept penal, vol. II, "Fundația Chemarea" Publishing House, Iaşi, G. Antoniu, Tipicitate şi antijuridicitate, "Revista de Drept Penal" Review, no. 4/1997;

Ioana Oancea, in V. Dongoroz (and collaborators), Explicații teoretice ale Codului penal roman, volume I, "Partea generală”, “Academiei” Publishing House, Bucharest, 1969;

Law no. 15 of 21.06.1968 - Codul penal al României, republished in Monitorul Oficial al României, Part. I, No. 65 of 16.04.1997, with subsequent amendments.

Pop, T., Drept penal comparat. Partea generală, volume II, Cluj, 1923. 